\title{
Ірина СТОРОНЯНСЬКА
}

доктор економічних наук, профресор, ДУ “Інститут регіональних досліджень імені М. Долішнього НАН України”, Львів, Україна, istoron.ird@gmail.com ORCID ID: 0000-0002-0237-1409

\section{Андріана БЕЛЯ}

аспірант, ДУ “Інституту регіональних досліджень імені М. Долішнього НАН України",

\section{ОСОБАИВОСТІ ТА ПРОБАЕМИ ЗДІЙСНЕННЯ ГРОМАДСЫКОГО КОНТРОАЮ ВИКОНАННЯ МІСЦЕВИХ БЮДХЕТІВ ТЕРИТОРІАИЫНИХ ГРОМАД}

\begin{abstract}
Вступ. Рефрорма децентралізації, що розпочалась у 2014 році, має на меті не лише зміну адміністративного устрою України, а й бюджетної системи, що може спричинити зростання потенційних ризиків неефективного використання бюджетних коштів. Для мінімізації негативних наслідків таких ризиків варто залучати громадськість, яка найбільше зацікавлена у досягненні цілей, визначених місцевим бюджетом громади.

Мета - ідентифрікувати особливості реалізації громадського контролю за використанням ресурсів місцевих бюджетах у територіальних громадах України.

Методи. У дослідженні використовували методи аналізу та синтезу для вивчення інструментів громадського контролю, а також опитування для виявлення поглядів активістів громадянського суспільства й експертів на заходи громадського контролю під час рефрорми децентралізації.

Результати. В роботі визначено рівні й інструменти громадського контролю виконання місцевих бюджетів територіальних громад. Виокремлено чотири рівні: інформування, консультування, діалог, партнерство. Наголошено на головних інструментах громадського контролю, серед яких: громадські слухання, елементи електронної демократії, консультативно-дорадчі органи, громадські ради та місцеві вибори.

Наведено результати соціологічного опитування громадських активістів та фрахівців у галузі місцевих фрінансів у Львівській та Харківській областях. За результатами анкетування виявлено значний рівень обізнаності респондентів щодо переліку інструментів громадського контролю. На думку більшості опитаних, громадські організації мають більші можливості контролювати витрати місцевих бюджетів, а обговорення використання бюджетних коштів є найбільш дієвим інструментом громадської участі.

Головними проблемами, за результатами опитування, в процесі використання бюджетних коштів є низький рівень прозорості бюджетного планування та виконання, а також низька ефективність наповнення та витрачання бюджетних коштів.
\end{abstract}

() Ірина Зеновіївна Сторонянська, Андріана Романівна Беля, 2020 
Виокремлено перешкоди у здійсненні громадського контролю за дотриманням ефрективного використання бюджетних коштів.

Перспективи. Подальші наукові дослідження громадського контролю за дотриманням бюджетів територіальних громад варто зосередити на юридичних особливостях таких заходів, а також перспективах використання визначених у статті інструментів у майбутньому.

Ключові слова: громадський контроль, місцевий бюджет, територіальна громада.

Рис.: 5, бібл.: 22.

\section{Ирина СТОРОНЯНСКАЯ}

доктор экономических наук, профрессор, ГУ “Институт региональных исследований имени М. Долишнего НАН України", Львов, Украина

\section{Андриана БЕЛЯ}

аспирант ГУ “Институт региональных исследований имени М. Долишнего НАН України", Львов, Украина

\section{ОСОБЕННОСТИ И ПРОБАЕМЫ ОСУЩЕСТВАЕНИЯ ГРАЖДАНСКОГО КОНТРОАЯ ВЫПОАНЕНИЯ МЕСТНЫХ БЮДХЕТОВ ТЕРРИТОРИАЯЬНЫХ СООБШЕСТВ: ПО РЕЗУАЬТАТАМ СОЦИОАОГИЧЕСКОЙ ОЦЕНКИ}

Введение. Рефрорма децентрализации, которая началась в 2014 году, имеет целью не только изменение административного устройства Украины, но и бюджетной системы, что может привести к росту потенциальных рисков неэффрективного использования бюджетных средств. Для минимизации негативных последствий таких рисков следует привлекать общественность, которая наиболее заинтересована в достижении целей, определенных местным бюджетом общины.

Цель - идентифицировать особенности реализации общественного контроля использования ресурсов местных бюджетов территориальных общин Украины.

Методы. В исследовании использовались методы анализа и синтеза для изучения инструментов общественного контроля, а також опрос для выявления взглядов активистов гражданского общества и экспертов на мероприятия общественного контроля в ходе реформы децентрализации.

Результаты. В работе определены уровни и инструменты общественного контроля выполнения местных бюджетов территориальных общин. Выделено четыре уровня: инфрормирование, консультирование, диалог, партнерство. Отмечено главные инструменты общественного контроля, к которым следует отнести: общественные слушания, элементы электронной демократии, консультативно-совещательные органы, общественные советы и местные выборы.

Приведены результаты социологического опроса общественных активистов и специалистов в сфрере местных фринансов Львовской и Харьковской областей. По результатам анкетирования выявлен значительный уровень осведомленности респондентов о перечне инструментов общественного контроля. По мнению большинства опрошенных, общественные организации имеют большие возможности контролировать расходы местных бюджетов, а обсуждение использования бюджетных средств является наиболее действенным инструментом общественного участия. 
Главными проблемами, по результатам опроса, в процессе использования бюджетных средств является низкий уровень прозрачности бюджетного планирования и выполнения, а также низкая эффрективность наполнения и расходования бюджетных средств. Выделен ряд препятствий в осуществлении общественного контроля над соблюдением эффрективного использования бюджетных средств.

Перспективы. Дальнейшие научные исследования общественного контроля за соблюдением бюджетов территориальных общин следует сосредоточить на юридических особенностях таких мероприятий, а также перспективах использования определенных в статье инструментов в будущем.

Ключевые слова: общественный контроль, местный бюджет, территориальная община.

\section{Iryna STORONYANSKA}

Dr. Sc. (Economics), Prof., SI "M. Dolishniy Institute of Regional Research of the NAS of Ukraine", Lviv, Ukraine, istoron.ird@gmail.com

ORCID ID: 0000-0002-0237-1409

\section{Andriana BELYA}

postgraduate student SI "M. Dolishniy Institute of Regional Research of the NAS of Ukraine", Lviv, Ukraine, ana1000@ukr.net

ORCID ID: 0000-0002-0706-8492

\section{FEATURES AND PROBLEMS OF PUBLIC CONTROL OVER THE IMPLEMEN- TATION OF LOCAL BUDGETS OF TERRITORIAL COMMUNITIES: ACCORDING TO THE RESULTS OF SOCIOLOGICAL ASSESSMENT}

Introduction. The decentralization reform, which began in 2014, aims not only to change the administrative structure of Ukraine, but also to change the budget system, which leads to an increase in potential risks of inefficient use of budget funds. To minimize the negative consequences of such risks, the public that is most interested in achieving the goals set by the local community budget should be used.

The purpose of the article is to identify the features of the implementation of public control over the use of resources of local budgets in the territorial communities of Ukraine.

Methods. The study used methods of analysis and synthesis to study the tools of public scrutiny and surveys to identify the views of civil society activists and experts on public scrutiny during decentralization reform.

Results. The levels and tools of public control over the implementation of local budgets of amalgamated communities were identified in this work. There are four levels: information, consultation, dialogue, partnership. Emphasis is placed on the main instruments of public scrutiny, which include: public hearings, elements of e-democracy, advisory bodies, public councils and local elections.

The results of a sociological survey (by conducting a survey) of public activists and specialists in the field of local finance in Lviv and Kharkiv regions are presented. According to most respondents, NGOs have more opportunities to control the spending of local budgets. The expediency of public control over local budgets was supported by the majority of respondents. 
Discussion of the use of budget funds, according to most respondents, is the most effective tool for public participation.

The main problems, according to the survey, in the process of using budget funds are the low level of transparency of budget planning and implementation, as well as low efficiency of filling and spending budget funds. According to the results of the study, a number of obstacles to public control over the effective use of budget funds were identified.

Descussion. Further research on public control over the observance of the budgets of territorial communities should focus on the legal features of such measures, as well as the prospects for the use of the tools defined in the article in the future.

Keywords: public control, local budget, local community

JEL Classification: R11.

Постановка проблеми. Реформи місцевого самоврядування й адміністративно-фрінансової децентралізації, які реалізують в Україні, спрямовані, з одного боку, на створення спроможних територіальних громад та зростання добробуту їх мешканців, з іншого - на підвищення відповідальності громадян за розвиток громад шляхом їх включення в процеси управління. В цих умовах питання громадського контролю за діяльністю органів місцевого самоврядування в громаді, зокрема щодо використання ресурсів місцевих бюджетів, $є$ надзвичайно актуальними. Громадський контроль за рухом фрінансових ресурсів громади дає змогу не лише забезпечити їх ефективне використання відповідно до ії основних потреб, а й вимагає від мешканців належного рівня знання бюджетного процесу та бюджетного законодавства, що сприяє підвищенню фрінансової грамотності учасників громадського контролю.

Аналіз останніх досліджень і публікацій. В Україні дослідження участі громадськості у роботі органів місцевого самоврядування розпочалися саме з початку активної фази реформи місцевого самоврядування та формування об'єднаних територіальних громад. Так, у роботах С. Савчук та Н. Коломийчук [1] ґрунтовно проаналізовано теоретичні аспекти громадського контролю та шляхів його посилення; праці Р. Ткаченка [2], К. Норенко [3] присвячені динаміці розвитку можливостей громадського контролю за державними органами на місцевому рівні; А. Неугодніков [4] розкриває юридичні аспекти громадського контролю; в роботах М. Терещенко [5], Л. Пристинської [6] обґрунтовано взаємозв'язок державного та громадського контролю за фрінансами громад.

Питання громадського контролю широко висвітлюється в публікаціях польських науковців. Наприклад, в роботах Д. Будзена [7] висвітлено особливості 25-річного досвіду існування місцевого самоврядування та можливості суспільства впливати на рішення ґмін. У працях Й. Випорської-Франкевич [8] розмежовано контроль і нагляд (зокрема громадський) за органами місцевого самоврядування, ідентифіковано роль відкритості інформації для громадськості. В тематичних дослідженнях А. Барщак [9], Б. Ракоці [10] особливо вирізняється екологічний напрямок і спроможність громади вплинути на екологічну ситуацію в регіоні. Існують глобальні дослідження громадської участі у роботі органів місцевого самоврядування. Наприклад, праці Європейського Трибуналу аудиторів 2019 р. [11] висвітлю- 
ють громадську активність в розрізі країн Європейського Союзу.

Метою статті $€$ виявлення особливостей реалізації громадського контролю за використанням ресурсів місцевих бюджетах у територіальних громадах в Україні.

\section{Виклад основного матеріалу дослі- дження.}

Рівні громадської участі та інструменти громадського контролю за ресурсами місцевих бюджетів територіальних громад.

На основі аналізу рівнів можливого впливу суспільства на прийняття органами влади управлінських рішень можна виокремити чотири рівні громадської участі, що вирізняються глибиною залучення зацікавлених осіб до процесу прийняття рішень, зокрема розподілу бюджетних коштів: інформування, консультування, діалог, партнерство.

Інформування - односторонні відносини, під час яких керівний орган ОТГ надає громадськості інформацію про формування, ухвалення, наповнення та використання бюджету ОТГ. Ці відносини передбачають як надання інформації за ініціативою органу влади, так і на вимогу громадськості [12].

Згідно з дослідженням за програмою "Децентралізація приносить кращі результати та ефективність (DOBRE)" [13], саме інформування $€$ основним рівнем спілкування у сучасних територіальних громадах в Україні. Основними проблемами на етапі оприлюднення інформації є:

- на веб-сайтах територіальних громад розміщують неповну інформацію щодо бюджетів, що ускладнює процес аналітичної оцінки;

- у більшості громад (80\%) на веб-сайтах розміщують інформацію щодо бюджету на поточний рік;

- практично відсутня інформація щодо поточного використання коштів місце- вих бюджетів, оприлюднюються лише річні звіти;

- лише 53\% досліджених громад оприлюднювали на власних сайтах паспорти бюджетних програм;

- практично відсутня аналітична інформація щодо планування та виконання місцевих бюджетів [13].

Консультації мають місце під час оприлюднення проєктів рішень органів місцевого самоврядування громади 3 метою отримання коментарів, зауважень, пропозицій від громадськості або обговорення проблем чи перспектив розвитку територіальної громади. Як правило, проведення консультацій ініціює орган управління.

Діалог може реалізовуватись у вигляді залучення представників громадськості до робочих груп, експертних рад тощо в процесі вироблення проектів конкретних нормативно-правових актів, рішень. Представники громадськості $€$ повноправними співучасниками процесу вироблення рішень. Діалог може бути ініційований як органом управління громади, так і громадськими організаціями, що визначено на рівні відповідного закону [14].

Партнерство - рівень взаємодії, коли орган державної влади та організації громадянського суспільства здійснюють взаємний обмін ресурсами (наприклад, делегування організаціям громадянського суспільства, надання певного виду послуг, спільне проведення заходів тощо) [12].

Реалізація громадського контролю за формуванням та виконанням місцевих бюджетів у територіальних громадах відбувається шляхом застосування низки інструментів (рис. 1).

Розглянемо найбільш дієві інструменти громадського контролю за ефективним використанням бюджетних коштів. Так, одним із них є загальні збори громадян за місцем проживання, що є формою їх прямої участі 


Інструменти громадської участі

Рис. 1. Інструментарій громадської участі в управлінні територіальними громадами* * Побудовано на основі [1, 4, 14].

у вирішенні питань місцевого значення. Ïх рішення враховують органи місцевого самоврядування в своїй діяльності. Для того, щоб загальні збори були легітимними, потрібно, щоб прийшло $50 \%+1$ від членів громади на відповідній території. Такий інструмент виписаний в ст. 8 Закону України "Про місцеве самоврядування в Україні" [15] та ставить обов'язок перед керівництвом територіальної громади обов'язково врахувати рішення громади, в тому числі і що стосується запитів та рекомендацій до місцевого бюджету [16].

Ще одним актуальним інструментом $€$ громадські слухання - найбільш поширений механізм місцевої демократії у більшості демократичних країн. Необхідність проведення громадських слухань найчастіше виникає, якщо:

- рішення, що його готує місцева влада, непопулярне і може спричинити соціальну напругу. Прикладом може слугувати перерозподіл бюджетних витрат на користь конкретного отримувача 3 ігноруванням інтересів інших учасників ОТГ;

- питання /проєкт має кілька альтернативних рішень;

- питання доволі складне й немає очевидних рішень;

- існує певне протистояння між органами влади та деякою групою територіальної громади.

Українська практика показує, що врегулювання процедури проведення слухань може бути здійснено як статутом громади, так і окремим положенням. Законом України "Про місцеве самоврядування в Україні” (стаття 13) встановлено, що громадські слухання мають відбуватися не рідше одного разу на рік [15].

Проте результати показують, що до об'єднання тільки 67,7\% територіальних громад застосовували інструмент громадських слухань, а після об'єднання - 92,9\% досліджуваних громад у Львівській та Харківській областях. Порядок проведення громадських слухань визначається Статутом 
територіальної громади. Однак виникає проблема наявності у відкритому доступі статутів громад. Так, станом на листопад 2018 р. з 35 громад Львівської області лише 4 оприлюднили на власних сайтах статути, а з 16 громад Харківської області - лише 2.

Місцеві ініціативи - це можливості для мешканців бути почутими, донести проблему до депутатів місцевих рад та відобразити позицію громади щодо порушеної проблеми. Важливість цього механізму громадської участі полягає в тому, що він дає право територіальній громаді ініціювати розгляд у місцевій раді будь-якого питання, що належить до ії̈ компетенції, яке є важливим для громади, але не виноситься на розгляд ради через небажання голови або депутатів. Порядок подання місцевих ініціатив встановлюється представницьким органом місцевого самоврядування або Статутом територіальної громади.

У випадку відсутності з боку органів управління громадою реакції на зазначені заходи громадської активності, зокрема щодо фрінансових питань, можливим $є$ проведення або місцевого референдуму, або дочасних виборів. Зауважимо, що місцевий референдум, як спосіб прийняття громадянами України рішень з важливих питань місцевого значення, не має правового забезпечення, оскільки Закон України щодо місцевих референдумів втратив чинність як неконституційний (згідно з рішенням Конституційного Суду України № 4-р/2018). У цьому контексті, на нашу думку, варто зазначити, що європейський досвід є вкрай актуальним в Україні, оскільки, наприклад, в Швейцарії [17] основні рішення приймають через фрінансові референдуми та збори в громаді, перелік яких може містити: напрями витрат громади; ставки податку в межах громади; впровадження нових податків; придбання, обмін або продаж землі громади; надання дозволу на будівництво тощо.
Зауважимо, що, згідно з чинним законодавством, будь-який громадянин України має право звернутися до органів місцевого самоврядування, об'єднань громадян, установ, організацій незалежно від фрорм власності, посадових осіб відповідно до їх функціональних обов'язків із зауваженнями, скаргами та пропозиціями, що стосуються їх статутної діяльності, заявою або клопотанням щодо реалізації своїх соціально-економічних, політичних та особистих прав і законних інтересів та скаргою про їх порушення [18].

На практиці, електронні звернення до органу місцевого самоврядування та зворотний зв'язок доступні на 23 веб-сайтах громад Львівської області (що становить $65,7 \%$ ) [19]. Водночас лише половина вебсайтів громад Харківської області володіє таким функціоналом.

Для органів місцевого самоврядування зростання кількості запитів, що стосуються ефективного витрачання бюджетних коштів, має бути сигналом для проведення додаткових перевірок та посилення самоконтролю. Прикладом таких інструментів може бути петиція, яка після набрання необхідного мінімуму $є$ обов'язковою для розгляду на засіданні органу управління територіальної громади.

Однак, незважаючи на наявність можливостей подати петицію на сайтах громад Львівської області, лише 19 веб-сайтів дають змогу зафріксувати петицію (з 40 наявних - 47,5\%) [20], крім цього, у статутах багатьох територіальних громад не зазначений необхідний мінімум голосів для розгляду цієї петиції. Для прикладу, Статутом м. Львова передбачено 500 голосів.

Громадські консультації - це відкритий діалог влади з мешканцями, що має на меті прийняття владою оптимальних рішень щодо суспільно важливих справ [21]. Консультації з громадськістю проводять 
й громадські ради у формі публічного обговорення, електронних консультацій (безпосередні форми) та вивчення громадської думки (опосередкована фрорма).

Зазначимо, що консультації мають відбуватися, базуючись на таких принципах: врахування інтересів зацікавлених сторін; наявності координатора, що об'єднує та спрямовує учасників у напрямку досягнення консенсусу; обов'язкового фріксування результатів та етапів консультування; доступності - всі зацікавлені особи повинні мати доступ до результатів консультацій; прозорості тощо.

Загалом результати перевірок громадськості чи органів державного фінансового контролю ефективності використання бюджетних коштів за попередні періоди можуть стати основою для проведення консультування та визначення громадськістю необхідності й доцільності спрямування обмежених фрінансових ресурсів ОТГ на визначені потреби громади.

У 2016 р. було затверджено Концепцію розвитку системи електронних послуг в Україні, що дала старт для застосування на місцевому рівні таких інструментів електронної демократії, як: громадський бюджет, різні форми електронних консультацій, електронні голосування і інші послуги. До прикладу, до середини 2018 р. українці ініціювали через Єдину систему місцевих петицій понад 12 тисяч петицій до місцевої влади. До системи приєдналися понад 170 громад.

Громадську експертизу широко використовують громадські організації в європейських країнах. Вона передбачає проведення інститутами громадянського суспільства, громадськими радами поточної оцінки діяльності органів місцевого самоврядування, ефективності прийняття і виконання такими органами рішень, підготовку пропозицій щодо вирішення зна- чущих проблем для їх врахування у своїй роботі [22]. Зауважимо, що за результатами дослідження тільки в 4 громадах Карпатського регіону з 70 опитаних застосовують інструмент “громадська експертиза”, водночас в 14 ОТГ є громадські ради, в 16 ОТГ - молодіжні ради і в 52 ОТГ - громадські організації.

32016 р. в Україні молодіжні ради змінили статус і функціонують в громадах як консультативно-дорадчий орган при відповідних органах влади, окрім цього, вони активно беруть участь у залученні грантового фрінансування розвитку громад.

Важливим фрактором становлення громадянського суспільства $є$ громадські об'єднання. До них належать як вузькоспеціалізовані (наприклад, Львівська обласна федерація Айкідо Айкікай, Львівська обласна організація Всеукраїнської екологічної ліги тощо), так і широкого профрілю (для прикладу, Буська районна Спілка політичних в'язнів і репресованих України, Центр політичних досліджень Золочівщини, громадська організація "Військово-спортивна січ” тощо). В розрізі територіальних громад спостерігається концентрація громадських об'єднань в міських ОТГ (як у Львівській, так і у Харківській областях). Загалом кількість зареєстрованих громадських об'єднань в громадах Львівської області $€$ меншою, аніж в громадах Харківської області.

Результати соціологічного опитування щодо здійснення громадського контролю в територіальних громадах. Задля виявлення ролі громадського контролю за функціонуванням місцевих бюджетів у 2020 р. було проведене соціологічне дослідження шляхом анонімного анкетування представників громадськості та експертів в галузі державного управління та контролю (працівники органів державної влади, співробітники апаратів управління територіальних громад та органів місцевого 
самоврядування, діяльність яких пов'язана із бюджетним процесом). В ході анкетування було опитано 91 громадського активіста та 54 експерти з Львівської та Харківської областей. Репрезентативність вибірки становить 95\% при середньому відхиленні 5\%.

Опитуванням було охоплено усі вікові групи громадських активістів та експертів, а також різні типи громад, в яких вони проживають (міські, сільські, селищні територіальні громади).

В ході анкетування було виявлено значно вищий рівень обізнаності можливостей та інструментарію громадського контролю серед представників органів управління в громаді, аніж серед громадських активістів - лише 83,3\% з них володіли інформацією про різні інструменти громадського контролю. Це може свідчити про недостатній рівень інформування населення про можливості участі мешканців в управлінні територіальною громадою.

На запитання: “Хто має долучатися до здійснення громадського контролю за використанням бюджетних коштів в громаді?" відповіді мешканців та представників органів управління дещо різняться (рис. 2).
Якщо громадські активісти наголошують на ролі представників місцевого самоврядування, то представники органів управління покладають більшу відповідальність на громадські організації.

Зауважимо, що на думку переважної більшості представників органів управління громади, участь громадських організацій у заходах громадського контролю є більш ефективною, ніж участь мешканців.

За результатами анкетування (рис. 3) можна стверджувати, що більшість анкетованих як експертів, так і громадських активістів вважають необхідним здійснення громадського контролю за бюджетними процесами на місцевому рівні. Так, 72,8\% експертів схиляються до думки, що громадський контроль за бюджетним процесом дасть змогу підвищити ефективність використання коштів місцевих бюджетів, а 66,7\% експертів вважають, що громадський контроль за бюджетним процесом не заважатиме органам місцевого самоврядування ефективно реалізовувати бюджетний процес.

Громадські активісти також стверджують, що органи управління в громаді дослухаються до думки громадськості у більшос-
Громадські організації

Громадські активісти

Усі небайдужі
Депутати місцевих рад
Представники місцевого
самоврядування
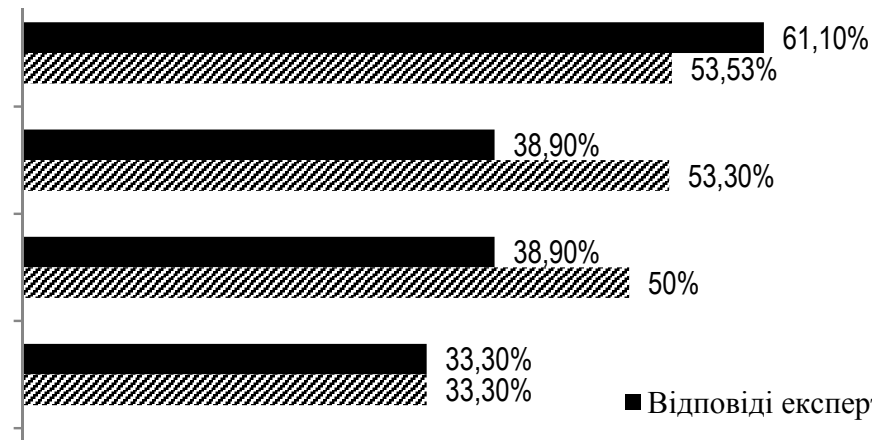

$33,30 \%$ $33,30 \%$ $30 \%$ — Відповіді експертів
च Відповіді громадських
активістів

Рис. 2. Розподіл відповідей на питання "Хто має долучатися до здійснення громадського контролю за використанням бюджетних коштів в ОТГ?”, \%*

* Побудовано на основі результатів проведеного опитування респондентів у 2020 p. 


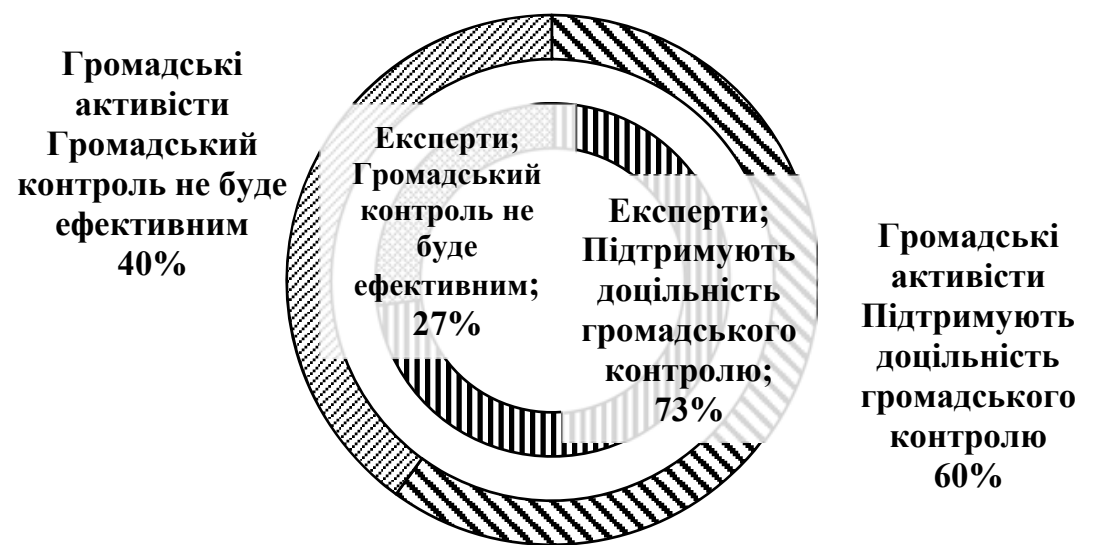

Рис. 3. Розподіл відповідей щодо доцільності здійснення громадського контролю за місцевими бюджетами територіальних громад, \%*

* Побудовано на основі результатів проведеного опитування респондентів у 2020 p.

ті випадків - 60\% опитаних громадських активістів зазначили, що їм відомі випадки впровадження пропозицій громадськості щодо внесення змін до бюджетів територіальних громад. При цьому вони фріксують зростання активності громадськості в громадському контролі за бюджетним процесом на місцевому рівні після початку сучасних ресрорм.

Одним із найскладніших для громадського контролю $є$ питання тендерних процедур. Так, лише у $31 \%$ опитаних громадських активістів є підтвердження залучення громадськості та громадських активістів до тендерних процесів у громадах. Оскільки за результатами проведення тендерів визначають підрядників на виконання, зокрема інфраструктурних проектів, зловживання при тендерному фінансуванні $\epsilon$ вагомою загрозою неефективного використання коштів місцевих бюджетів.

Проведене анкетування дало змогу сфрормувати перелік ключових інструментів громадської участі у бюджетному процесі (рис. 4).

При цьому варто зазначити існування різних підходів до розуміння таких інструментів з боку громадськості та з боку пред- ставників органів управління в громаді. Якщо другі до більш дієвих інструментів участі громадськості у бюджетному процесі відносять інструменти інформативного характеру (обговорення, звітність та експертизи), то, на думку громадських активістів, вищу ефективність забезпечує залучення мешканців громади до безпосередньої участі у контролі за використанням бюджету, зокрема через фрормування громадських рад.

Оскільки управлінські заходи потребують контролю за ефективністю їх виконання, опитаним було запропоновано визначити перелік інструментів громадського моніторингу за місцевими бюджетами. На першому місці, за результатами анкетування активістів, є громадські слухання як інструмент управління бюджетними ресурсами в ОТГ - 41,4\%, на думку ж експертів, цей інструмент моніторингу бюджетних процесів посідає лише друге місце, і з цим згідні $27,8 \%$ опитаних респондентів-експертів.

На думку експертів у ссрері місцевого управління, найбільш вагомими причинами, що породжують неефективне використання бюджетних коштів, є: низький рівень 
обговорення використання бюджетних коштів, звітів

публікації звітів про виконання місцевих бюджетів

проведення громадських експертиз

публічні обговорення бюджету на радіо або телебаченні

формування громадських рад

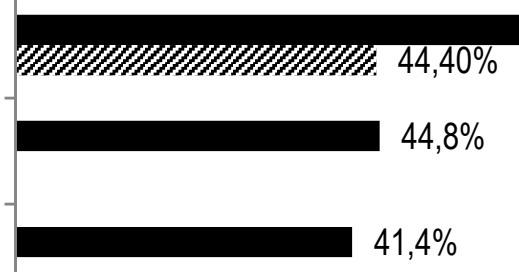

$62,1 \%$

$-$

- відповіді експертів $\quad$ ஜ відповіді громадських активістів

$55,60 \%$

Рис. 4. Розподіл відповідей на питання “Які, на вашу думку, інструменти громадської участі у бюджетному процесі є найбільш дієвими?”, \% *

* Побудовано на основі результатів проведеного опитування респондентів у 2020 р.

прозорості бюджетного планування та виконання (72,2\% опитаних вибрали цю причину), неефективне використання коштів місцевих бюджетів (недоцільне преміювання працівників, нераціональні закупівлі тощо) (66,7\% респондентів) та проведення тендерних процедур із підготовленими ви- могами під конкретного переможця (55,6\% анкетованих осіб) (рис. 5).

Що стосується думки громадських активістів, то 63,3\% респондентів серед запропонованих проблем у бюджетному процесі ОТГ відзначили неефективне використання коштів місцевих бюджетів (недоцільне

низький рівень прозорості бюджетного планування та виконання

неефективне використання коштів місцевих бюджетів (недоцільне... проведення тендерних процедур із підготовленими вимогами під...

відсутність видатків на розвиток ОТГ (лише на споживання)

корупція в органах управління в ОТГ хронічний (регулярний) дефіцит місцевого бюджету

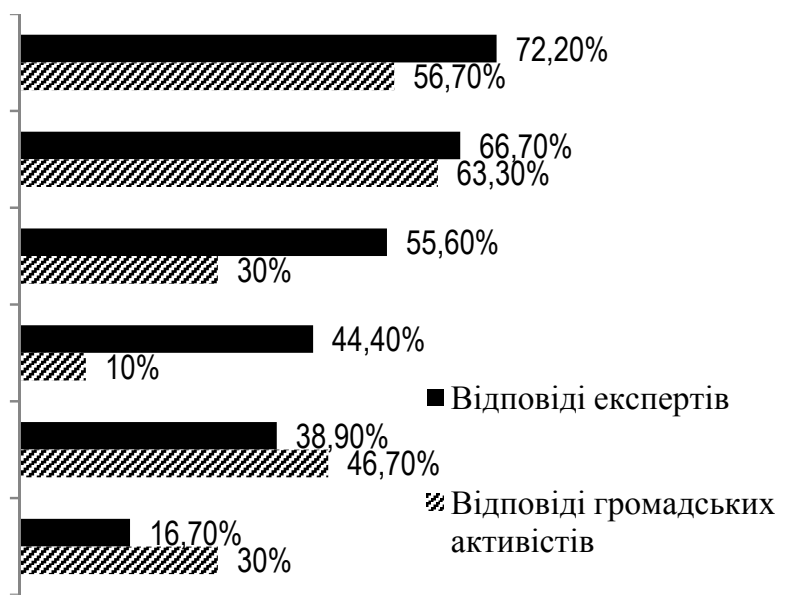

Рис. 5. Розподіл відповідей на питання “Які, на вашу думку, із перелічених проблем є найгострішими в питанні використання бюджетних коштів територіальних громад?”, \%*

* Побудовано на основі результатів проведеного опитування респондентів у 2020 р. 
преміювання працівників, нераціональні закупівлі тощо); 56,7\% - низький рівень прозорості бюджетного планування та виконання, 46,7\% - корупцію в органах управління територіальною громадою.

Хронічний дефіцит місцевого бюджету, як причину низької ефективності використання бюджетних коштів територіальних громад, визначили $16,7 \%$ експертів та $30 \%$ громадських активістів, однак, за своєю суттю, десріцит $€$ наслідком, відображенням неефективності використання бюджетних коштів.

Підсумовуючи, зазначимо, що й експерти, і громадські активісти вбачають проблеми в процедурах розподілу бюджетних коштів на місцевому рівні, в тому числі серед проблем, що потребують вирішення, виокремлюють і низьку прозорість процедури розподілу коштів, і корупційну складову.

Висновки. Основними інституційно-організаційними перешкодами забезпечення ефективності громадського контролю у бюджетному процесі територіальної громади є:

- недосконалість інституційних засад застосування низки інструментів громадської участі, зокрема таких, як місцевий референдум, що потенційно призводить до непрозорості процесу прийняття рішення органами місцевого самоврядування та нівелювання можливості впливу громадськості на процес прийняття рішення;

- низький рівень інформаційної прозорості використання бюджетних ресурсів у територіальних громадах, що ускладнює процедуру громадського контролю актуальних бюджетних витрат громад;

- низький рівень використання громадської експертизи як ефективного інструменту громадського контролю за бюджетними потоками в громаді;

- використання місцевими органами влади елементів електронної демократії лише для інформування громадян про власні рішення;

- низький рівень обізнаності мешканців громади в питаннях можливості власної участі у процесах громадського контролю за використанням бюджетних ресурсів територіальної громади.

Слід зазначити, що процеси децентралізації фрінансових ресурсів та перенесення низки функцій на базовий рівень управління суттєво активізували громадськість у питаннях здійснення громадського контролю. Як результат, має місце зростання фрінансової грамотності населення (зокрема мешканців сільських територіальних громад) в частині фрормування та використання бюджетних ресурсів на місцевому рівні, а також поступове включення мешканців в процеси управління соціальноекономічним розвитком територіальних громад. Це свідчить про розуміння мешканців громад спільної відповідальності за власний добробут.

\section{Список використаних джерел}

1. Савчук С. В., Коломийчук Н. М. Теоретичні аспекти громадського контролю. Гроші, фрінанси і кредит. 2018. № 24. C. 364-368. URL : http://www.market-infr.od.ua/ journals/2018/24_2018_ukr/63.pdf.

2. Ткаченко Р. О. Стан та розвиток громадського контролю за діяльністю органів Національної поліції України. Науковий вісник Львівського державного університету внутрішніх справ. 2018. № 4. C. 198-205. URL : http://www.Ivduvs.edu.ua/documents pdf/visnyky/ nvsy/nvsy_04_2018/23.pdf.

3. Норенко К. Громадський контроль за використанням коштів фондів охорони навколишнього природного середовища. URL : http://epl.org.ua/wp-content/uploads/2019/03/ Instruktsiya-dlya-gromadskosti.pdf.

4. Неугодніков А. О. Громадський контроль за діяльністю суб'єктів публічної адміністра- 
ції: наближення до міжнародних стандартів. LEX PORTUS. 2019. № 6 (20). C. 66-79. URL : http://dspace.onua.edu.ua/bitstream/handle/11300 112312/\%D0\%9D\%D0\%B5\%D1\%83\%D0\%B3\%D O\%BE\%D0\%B4\%D0\%BD\%D0\%B8\%D0\%BA\%D O\%BE\%D0\%B2\%20\%D0\%93\%D1\%80\%D0\%BE. pdf? sequence $=1$ \&isAllowed $=y$.

5. Терещенко М. М. Взаємозв 'язок державного та громадського контролю як інструмент реалізації публічного управління : автореср. дис. ... канд. наук з держ. упр.: 25.00.02. Київ, 2020, 20 c.

6. Пристинська Л. І. Особливості здійснення громадського контролю в системі органів місцевого самоврядування в Україні. 2019. URL : https://krs.chmnu.edu.ua/jspui/bitstream/1234567 89/715/1/\%D0\%B0\%D0\%B2\%D1\%82\%D0\%BE\% D1\%80\%D0\%B5\%D1\%84\%D0\%B5\%D1\%80\%D 0\%B0\%D1\%82 \%D0\%9F\%D1\%80\%D0\%B8\%D1 $\% 81 \% D 1 \% 82 \% D 0 \% B 8 \% D 0 \% B D \% D 1 \% 81 \% D 1 \%-$ 8C\%D0\%BA\%D0\%B0.pdf.

7. Budzeń D. Ewolucja systemu kontroli wewnętrznej w jednostkach samorządu terytorialnego na przestrzeni 25 lat samorządności w Polsce. Ruch prawniczy, ekonomiczny i socjologiczny. 2015. № LXXVII. S. 287-301. URL : http://pressto.amu.edu.pl/index.php/rpeis/article/ download/3133/3121.

8. Wyporska-Frankiewicz J. Kontrola wykonywania zadań i nadzór nad jednostkami samorządu terytorialnego : monografia. Wolters Kluwer business. 2020. 212 s. URL : https://sip.lex.pl/ komentarze-i-publikacje/monografie/kontrola-wykonywania-zadan-i-nadzor-nad-jednostkami-samorzadu-369469114.

9. Barczak A. Zadania kontrolno-nadzorcze samorządu terytorialnego w zakresie ochrony środowiska. Ekspertyzy i opracowania. 2019. № 96. P. 1-8. URL : https://www.nist.gov.pl/files/ zalacznik/1577108262_EiOP\%20nr\%2096_2019.pdf.

10. Rakoczy B. Prawo ochrony środowiska. Komentarz. Warszawa, 2008. URL : https://sip. lex.pl/komentarze-i-publikacje/komentarze/prawoochrony-srodowiska-komentarz-587609947.
11. Kontrola publiczna w Unii Europejskiej. Europejski trybunał obrachunkowy. 2019. 228 p. URL : https://www.eca.europa.eu/Lists/ ECADocuments/Book Public Audit in the EU/ Book-Public Audit in the EU PL.pdf.

12. Купрій В. Як оцінка допомагає робити врядування більш відкритим та підзвітним? Національне агентство України з питань державної служби. 2019. URL : http://www.ua.undp. org/content/dam/ukraine/docs/DG/A4UA.pdf.

13. Результати оцінювання управління фрінансами об'єднаних територіальних громад. URL : https://storage.decentralization.gov. ua/uploads/library/file/273/DOBRE UA FMA Results.pdf.

14. Про соціальний діалог в Україні : Закон України від 23.12.2010 р. № 2862-VI. URL : https:// zakon.rada.gov.ua/laws/show/2862-17\#Text.

15. Про місцеве самоврядування в Україні : Закон України від 21.05.1997 р. № 280/97BP. URL : https://zakon3.rada.gov.ua/laws/ show/280/97-\%D0\%B2\%D1\%80.

16. Врублевський О. Що потрібно знати старості про юридичну природу загальнuх зборів громадян. DESPRO. URL : https:// decentralization.gov.ua/news/10260.

17. Здійснення громадського контролю у зарубіжних країнах. URL : http://euinfocenter.rada. gov.ua/uploads/documents/29223.pdf.

18. Про звернення громадян : Закон України від 02.10.1996 р. № 393/96-BP. URL : https://zakon2.rada.gov.ua/laws/show/393/96$\% D 0 \% B 2 \% D 1 \% 80$.

19. Літвінова К., Маєвська О. Яка інфрормація є на офріційних веб-сайтах ОТГ Львівської області. URL : http:///bit.do/eEjhT.

20. Літвінова К., Маєвська О. Яка інформація $\epsilon$ на офріційних веб-сайтах ОТГ для доступу до електронних сервісів та інструментів електронної демократії? URL : https://egromada.files.wordpress.com/2018/08/ dObbd18cd0b2d196d0b2d181d18cd0bad0b0dObed0b1dObbdOb0d181d182d18c.pdf. 


\section{ДЕРЖАВНІ I МІСЦЕВI ФІНАНСИ}

21. Про громадські об'єднання : Закон України від 22.03.2012 р. № 4572-VI. URL : http:// zakon2.rada.gov.ua/laws/show/4572-17.

22. Про затвердження Порядку сприяння проведенню громадської експертизи діяльності органів виконавчої влади. Постанова Кабінету Міністрів України № 976 від 05.11.2008. URL : https://zakon.rada.gov.ua/laws/show/9762008-\%D0\%BF.

\section{References}

1. Savchuk, S., Kolomyychuk, N. (2018). Teoretychni aspekty hromadskoho kontroliu [Theoretical aspects of public control] Hroshi, finansy $i$ kredyt - Money, Finance and Credit, 24, 364-368. Available at: http://www.market-infr.od.ua/jour-

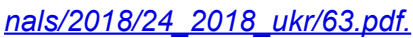

2. Tkachenko, R. (2018). Stan ta rozvytok hromadskoho kontroliu za diialnistiu orhaniv Natsionalnoii politsii Ukrainy [Status and development of public control over the activities of the National Police of Ukraine]. Naukovyi visnyk Lvivskoho dershavnoho universytetu vnutrishnikh sprav - Scientific Bulletin of Lviv State University of Internal Affairs, 4, 198205. Available at: http://www.lvduvs.edu.ua/documents pdf/visnyky/nvsy/nvsy 04 2018/23.pdf.

3. Norenko, K. (2019). Hromadskyi kontrol za vykorystanniam koshtiv fondiv okhorony navkolyshnoho pryrodnoho seredovyshcha [Public control over the use of environmental funds]. Available at: $\quad$ http://epl.org.ua/wp-content/uploads/2019/03/ Instruktsiya-dlya-gromadskosti.pdf:

4. Neugodnikov, A. (2019). Hromadskyi kontrol za diialnistiu subyektiv publichnoi administratsii: nablyzhennia do mizhnarodnykh standartiv [Public control over the activities of public administration: approximation to international standards]. LEX PORTUS, 6 (20), 66-79. Available at: http:// dspace.onua.edu.ua/bitstream/handle/11300/12 $312 / \%$ D0\%9D\%D0\%B5\%D1\%83\%D0\%B3\%DO $\% B E \% D 0 \% B 4 \% D 0 \% B D \% D 0 \% B 8 \% D 0 \% B A \% D 0$ $\% B E \% D 0 \% B 2 \% 20 \% D 0 \% 93 \% D 1 \% 80 \% D 0 \% B E$. pdf? sequence $=1$ \&isAllowed $=y$.
5. Tereshchenko, M. (2020). Vzaiemozviazok derzhavnoho ta hromadskoho kontroliu yak instrument realizatsii publichnoho upravlinnia [Interrelation of the state and public control as the tool of realization of public management]. (Thesis: 25.00.02). Kyiv [in Ukrainian].

6. Prystynska, L. (2019). Osoblyvosti zdiisnennia hromadskoho kontroliu $v$ systemi orhaniv mistsevoho samovriaduvannia $v$ Ukraini [Features of public control in the system of local self-government in Ukraine]. Available at: https://krs.chmnu.edu.ual ispui/bitstream/123456789/715/1/\%D0\%B0\%D0\%B 2\%D1\%82\%D0\%BE\%D1\%80\%D0\%B5\%D1\%84\% D0\%B5\%D1\%80\%D0\%B0\%D1\%82 \%D0\%9F\%D $1 \% 80 \% D 0 \% B 8 \% D 1 \% 81 \% D 1 \% 82 \% D 0 \% B 8 \% D 0 \%$ BD\%D1\%81\%D1\%8C\%D0\%BA\%D0\%B0.pdf.

7. Budzeń, D (2015). Ewolucja systemu kontroli wewnętrznej w jednostkach samorządu terytorialnego na przestrzeni 25 lat samorządności $w$ Polsce. Warsaw. Ruch prawniczy, ekonomiczny $i$ socjologiczny, LXXVII, 287-301. Available at: http:// pressto.amu.edu.pl/index.php/rpeis/article/download/3133/3121.

8. Wyporska-Frankiewicz, J. (2020). Kontrola wykonywania zadań i nadzór nad jednostkami samorządu terytorialnego. Wolters Kluwer business. Available at: https://sip.lex.pl/ komentarze-i-publikacje/monografie/kontrola-wykonywania-zadan-i-nadzor-nad-jednostkami-samorzadu-369469114.

9. Barczak, A. (2019). Zadania kontrolnonadzorcze samorządu terytorialnego w zakresie ochrony środowiska. Ekspertyzy i opracowania, 96, 1-8. Available at: https://www.nist.gov.pl/files/zalacznik/1577108262 EiOP\%20nr\%2096 2019.pdf.

10. Rakoczy, B. (2008). Prawo ochrony środowiska. Komentarz. Warsaw. Available at: https://sip.lex.pl/komentarze-i-publikacje/komentarze/prawo-ochrony-srodowiska-komentarz-587609947.

11. Kontrola publiczna w Unii Europejskiej. Eurepejski trybunal obrachunhowy. (2019). Available at: https://www.eca.europa.eu/Lists/ECADoc- 


\section{ДЕРЖАВНI I МІСЦЕВI ФІНАНСИ}

uments/Book Public Audit in the EU/Book-Public Audit in the EU PL.pdf.

12. Kupriy, B. (2019). Yak otsinka dopomahaie robyty vriaduvannia bilsh vidkrytym ta pidzvitnym? [How does evaluation help make governance more open and accountable?]. Nationalne ahentstvo Ukrainy z pytan dershavnoi sluzhby - National Agency of Ukraine for Civil Service Affairs. Available at: http://www.ua.undp.org/content/dam/ ukraine/docs/DG/A4UA.pdf.

13. Rezultaty otsiniuvannia upravlinnia finansamy obiednanykh terytorialnykh hromad [Results of the evaluation of the financial management of amalgamated local communities]. Available at: https://storage.decentralization.gov.ua/uploads/library/file/273/DOBRE UA.

14. Pro sotsialnyi dialoh $v$ Ukraini. Zakon Ukrainy vid 23.12.2010 r. № 2862-VI. [On social dialogue in Ukraine. Law of Ukraine № 2862-VI]. (2010, December, 25). Available at: https://zakon. rada.gov.ua/laws/show/2862-17\#Text.

15. Pro mistseve samovriaduvannia v Ukraini: Zakon Ukrainy vid 21.05.1997 r. № 280/97-VR. [On local self-government in Ukraine. Law of Ukraine № 280/97-BP]. (1997, May, 21). Available at: https://zakon3.rada.gov.ua/laws/show/280/97$\% D 0 \% B 2 \% D 1 \% 80$.

16. Vrublevsky, O. (2018). Shcho potribno znaty starosti pro yurydychnu pryrodu zahalnykh zboriv hromadian [What do monitor need to know about the legal nature of the general meeting of citizens]. DESPRO. Available at: https://decentralization.gov.ua/news/10260.

17. Zdiysnennia hromadskoho kontroliu u zarubizhnykh krainakh [Implementation of public control in foreign countries]. Available at: $\underline{\text { http://euinfo- }}$ center.rada.gov.ua/uploads/documents/29223.pdf.
18. Pro zvernennia hromadian: Zakon Ukrainy vid 02.10.1996 r. № 393/96-VR. [On citizens' appeals. Law of Ukraine of № 393/96-VR]. (1996, October, 2). Available at: https://zakon2.rada.gov.ual laws/show/393/96-\%D0\%B2\%D1\%80.

19. Litvinova, K., Maievska, O. Yaka informatsiia ye na ofitsiinykh veb-saitakh OTH Lvivskoi oblasti [What information is on the official websites of ALC of Lviv region]. Available at: http://bit.do/ eEihT.

20. Litvinova, K., Maievska, O. Yaka informatsiia ye na ofitsiinykh veb-saitakh OTH dlia dostupu do elektronnykh servisiv ta instrumentiv elektronnoi demokratii? [What information is available on the official ALC websites for access to electronic services and tools of e-democracy?]. Available at: https://egromada.files. wordpress.com/2018/08/ dObbd18cd0b2d196d0b2d181d18cd0bad0b0dObed0b1d0bbd0b0d181d182d18c.pdf.

21. Pro hromadski obiednannia. Zakon Ukrainy vid 22.03.2012 r. № 4572-VI. [On public associations. Law of Ukraine № 4572-VI]. (2012, March, 22). Available at: http://zakon2.rada.gov.ua/laws/ show/4572-17.

22. Pro zatverdzhennia Poriadku spryiannia provedenniu hromadskoi ekspertyzy diialnosti orhaniv vykonavchoi vlady. Postanova Kabinetu Ministriv Ukrainy vid 05.11.2008 № 976 [On approval of the Procedure for promoting public examination of the activities of executive bodies. Resolution of the Cabinet of Ministers of Ukraine № 976]. (2008, November, 05). Available at: https://zakon. rada.gov.ua/laws/show/976-2008-\%D0\%BF.

Стаття надійшла до редакції 8.09.2020. 